\title{
FEMALE DIRECTORS AND SMES: AN EMPIRICAL ANALYSIS
}

\author{
*Antonio MÍNGUEZ-VERA \\ **Raquel LÓPEZ-MARTÍNEZ \\ *University of Murcia \\ **CARM
}

\begin{abstract}
The topic of gender has attracted the interest of researchers in recent years. However, most empirical results are based on listed firms. The aim of this paper is to study gender diversity on boards of directors in a sample of 10,786 Spanish small and medium enterprises (SMEs) using panel data analysis. The results show that gender diversity in the boardroom has a positive effect on firm performance. Also, the presence of an individual who is a main shareholder has a positive impact on female representation on the board of directors. In contrast with this, having a non-financial firm as principal shareholder diminishes the probability that women will be appointed to the board. The results indicate that women directors prefer to be on the boards of firms with less financial risk. Finally, smaller firms and larger boards include more women as directors.
\end{abstract}

Keywords: Gender, SME's, directors

\section{INTRODUCTION}

In recent years there has been a pressure from society to include women on the boards of directors of corporate bodies. As result, in Europe, the average number of women in boardrooms has increased in recent years (Heidrick and Struggles, 2007). However, female representation is still at a low level compared to the U.S. and there is wide variation across countries. At the same time, scholars have studied the effects of the presence of women in the boardroom. They argue that women directors can have an important influence on the way that the board works, its working style and board processes, and, consequently, on firm performance (Kesner, 1988; Bilimoria and Piderit, 1994; Daily et al., 1999; Farrell and Hersch, 2005).+

The majority of studies that examine board diversity focus on large firms. Recently, a number of researchers have addressed the need to study the board of directors as a potential resource in Small and Medium-sized Enterprises (SMEs) that can lead to competitive advantage and improved firm performance (Gabrielsson, 2003), and women can offer many contributions to the effectiveness of the board (Bilimoria, 1995, and Segal, 1996).

The present study focuses on gender representation on boards of directors in SMEs in Spain, which is one of the countries with the lowest level of female representation on boards in the European Union. In response to the challenge of under-representation of women on boards, two legislative measured have recently been passed in Spain: the Unified Good Governance Code (2006) and the Gender Equality Act (Ley de Igualdad, 2007), similar to the one passed in Norway (2003).

The objective of this paper is to answer the following questions: How are women directors important in Spanish SMEs? Does gender diversity of Spanish boards of directors of SMEs have any impact on firm performance? What characteristics of Spanish SMEs influence the presence of women on boards? By addressing these questions, the present study contributes to the literature in several ways. First, it provides empirical evidence from Spain, where there has been an open debate about gender equality based on the legislative changes in favor of women.

Second, the study focuses on SMEs, which is an area that has been ignored by the majority of empirical studies that have been undertaken. By focusing on SMEs, the study examines the firms where the majority of the employment is generated. 
The paper is structured as follows. In Section 2 the theoretical arguments are developed and the Spanish context described. Section 3 reports the data selection and the sample. Section 4 describes the methodology applied and Section 5 presents the results. The main conclusions are in the final section.

\section{BOARD DIVERSITY}

Recently, researchers have begun to investigate work group diversity (Bracatto and Patterson, 1999 and Carter et al., 2003; among others), defined as the variety of individual attributes within a group (Blau, 1977). Milliken and Martins (1996) differentiate between two types of diversity: observable and non-observable. Observable diversity is related to detectable attributes such as race, age or gender. These differences between people are visible and they can be connected with bias, prejudice and stereotypes. Non-observable diversity is associated with less visible or underlying attributes such as education, technical abilities, functional background, length of service in the organization, socioeconomic background, personality characteristics or values (Milliken and Martins, 1996; Cummings et al., 1993; Jackson et al., 1995; Tsui et al., 1992).

The literature about the effects of diversity on the performance of work groups is extensive and varied. Robinson and Dechant (1997) argue that greater diversity in working groups implies a better knowledge of the market and a best identification with customers and employees, and thus it makes easier to operate in markets. Similarly, Morrison (1992) affirms that diversity in the organizational decision making group may lead to higher quality decisions, since the thinking of the group will be more realistic and complex. So, diversity can increase creativity and innovation and can improve problem-solving (Robinson and Dechant, 1997).

Milliken and Martins (1996) and Fray and Guillaume (2007) suggest that a diverse team has access to a larger network and, associated with this, access to a larger pool of information, skills, and support that fall within the network.

Furthermore, communication between the top management group and non-members may be more frequent and of higher quality when the team representatives come from many different areas of the organization (Ancona and Caldwell, 1988) and organizational outcomes may be improved because the composition of some organizational groups has symbolic significance for both external and internal stakeholders (Ely, 1994; Hambrick, 1994; Pfeffer, 1981).

There are also arguments that greater diversity may have negative effects on group outcomes. A more diverse group can be less integrated and the likelihood of dissatisfaction and turnover is higher (Wagner et al., 1984; Jackson et al., 1991; Milliken and Martins, 1996). Heterogeneous groups are more likely to present communication and coordination difficulties that reduce the effective use of knowledge and skills, and result in less cohesion and interpersonal attraction and fewer mutually satisfying interactions among members (Forbes and Milliken, 1999). Therefore, it is more likely that heterogeneous groups spend more time in meeting preparation, discussion of questions and taking decisions (Lau and Murnighan, 1998).

In this study the focus is on gender diversity in boardrooms. Several studies identify the importance of women directors. For example, Daily and Dalton (2003) considerer that increasing the female representation on the board is a business imperative. They provide a number of reasons:

First, in a complex business environment, firms must use all available resources to compete effectively and women represent half of the workforce. It is not logical to waste the skills, expertise and background knowledge of females, which could be used to improve the effectiveness of the board of directors.

Second, the presence of females on the board can send a signal to women in business and to women in general. They can play a role as models to promote the breaking of the "glass ceiling" and be considered important "tokens". And third, women on the board of directors can have positive effects on the bottom line.

At the same time, in recent years, there has been increasing pressure from both society and investors to appoint women directors to corporate boards. These pressures have been represented in equality laws in some countries, including Spain, where there is an open debate about diversity on boards of 
directors and in society generally. For this reason, the study of the gender situation in the Spanish context is interesting.

After acknowledging the importance of female representation on boards of directors, it is interesting to analyze the various contributions that women can make to the board. In other words, how does gender diversity contribute to the board?

Daily and Dalton (2003) affirm that women directors provide unique perspectives, experiences and work styles as compared to their male counterparts. They can enhance the board's deliberations and their communication style is more participative and process-oriented. The presence of women may enhance decision-making processes by encouraging the board to considerer more strategic options and a variety of customer needs and interests. The presence of women may improve the image of the firm and this may have a positive effect on customer behaviour (Smith et al., 2006) and can introduce more creative discussion on the boards.

Erkut (2006) studies the corporate governance behaviour of women directors. He shows that women are more likely than men to ask tough questions in the boardroom and demand direct and detailed answers.

Women directors have non-traditional backgrounds and experiences (Hillman et al., 2002), have fewer relationships with boards of other firms (Zelechowski and Bilimoria, 2004), are less likely to have business occupations (Kesner, 1988) and are qualitatively oriented while men are quantitatively oriented (Loden, 1985), to support his argument that women are more successful in specific tasks. Women directors may exert a positive influence in tasks relating to corporate social responsibility and strategic control and a negative influence in tasks relating to finance and operational control.

In contrast with this, Brancato and Patterson (1999) and Adams and Ferreira (2002) argue that the gender of a board member does not imply any different behaviour in the management of the firm.

Finance and accounting researchers have investigated the influence of women directors on firm performance. These studies, like the present study, have tested for a direct relationship between the presence of women on the board and firm performance.

The empirical evidence is inconclusive. For example, Shrader et al. (1997) find non significant or negative influence of gender diversity on accounting measures of performance in the United States. Carter et al. (2003) find a positive and significant relationship between Tobin's Q and the proportion of women on the boards of Fortune 1000 firms. Similar results are obtained by Welbourne et al. (2007). Erhardt et al. (2003) show a positive relationship between the percentage of women on the boards of listed United States firms and performance. Similarly, Catalyst (2004) shows higher levels of returns for firms with more women in their top management teams for a sample of Fortune 500 companies. Harel et al. (2003) find that women promoted into management achieve better results in terms of performance and effectiveness. Jehn and Bezrukova (2004) report a negative and significant relationship between the percentage of female board members and several accounting measures of financial value. Fenwick and Neal (2001) find that gender composition is related to some measures of performance but not to others. Watson et al. (1993) and Richard (2000) identify a non-significant relationship between gender diversity and firm performance.

In Europe, Du Rietz and Henrekson (2000), for a sample of Swedish firms, and Smith et al. (2006) and Rose (2007), for Danish companies, do not find any influence of the presence of women on the boards on performance. A similar result was obtained by Randøy et al. (2006) for larger firms from several Scandinavian countries (Denmark, Norway, and Sweden). However, Böhren and Ström (2007) report a negative relationship of the presence of women on Norwegian board of directors and firm value.

For the Spanish market, Mateos et al. (2006) find that firms with highest or lowest levels of performance of the largest Spanish firm have fewer women on their boards.

The majority of previous evidence is focused on listed firms. However, the interest in the boards of SMEs has increased in recent years (Daily et al., 2002; Warren, 2003; Gabrielson, 2003). Forbes and Milliken (1999) identify several differences between boards of directors of SMEs and listed firms. 
They argue that SMEs tend to be undiversified, less structurally complex, and less formalized. Therefore, the range and depth of service activities available to the boards of small firms are likely to be greater (Castaldi and Wortman, 1984, and Judge and Zeithaml, 1992). These circumstances can form a stronger link between the board's service contributions and firm performance (which confirms the findings of Hambrick and Finkelstein, 1987). The directors of small firms may be entrepreneurs with relatively little general experience, and the board's knowledge and skills may be a particularly critical ingredient of its own effectiveness (Gorman and Sahlman, 1989). Finally, share ownership is usually more concentrated in SMEs, which implies that shareholders are often represented directly on the boards and the control function is less important because shareholder rights and managerial responsibilities will reside in the same people (Forbes and Milliken, 1999). In this way, it is possible that, on the board of an SME, women assume more of a service role than a control role.

It is likely that board composition is more important in the decision-making process in SMEs because in smaller groups each director can have more power. Consequently, directors' power is increased because there is less separation between ownership and control.

In accordance with the majority of theoretical arguments and the empirical evidence, the following hypothesis is proposed: Hypothesis 1: gender diversity on boards of directors will have a positive effect on firm performance.

Farrell and Hersch (2005) argue that, as women directors are a rare resource, they can select boardrooms of firms with higher levels of performance. This suggests Hypothesis 2: a positive relationship between the performance of a firm and the presence of women on the board is expected (Adams and Ferreira, 2002).

On the other hand, Jianakoplos and Bernasek (1998) argue that women are more risk-averse than men (Chaganti, 1986; Brown and Segal, 1989; Collerette and Aubry, 1990; Olsen and Currie, 1992; Scherr et al., 1993).Taking into account these arguments, the following is suggested: Hypothesis 3: if women are risk adverse, they will choose to serve on the boards of firms with less risk.

Finally, the following hypothesis is derived from the research of Mateos et al. (2006): Hypothesis 4: firms with an individual main shareholder are more prone to adding women to the board for family reasons.

\section{SAMPLE AND DATA}

Data were collected from the SABI database. This database provides information on 900,000 Spanish firms. Once firms with no data and with erroneous data are excluded, as well as firms presenting extreme values, the remaining firms were used to construct an unbalanced panel comprising 10,786 companies and 43,213 observations.

Gender diversity has been measured in several ways. First, by the "Presence of women" that is a binary variable that indicates the presence, at least, of a woman on the board. Second, the "Women ratio" is included and calculated as the number of women on the board of directors divided by the total number of directors. Finally, two measures (See Harrison and Klein, 2007 and Stirling, 1998) are considered that relate to the two gender categories, variety, and the uniformity of the distribution of directors across them, balance. The first one is the Blau index (Simpson, 1949 and Blau, 1977) calculated

$$
1-\sum_{i=1}^{n} P_{i}^{2}
$$

as $\quad{ }_{i=1} \quad$, where $P_{i}$ represents the percentage of directors in each category (women or men) and $n$ is the number of categories. The maximum and the minimum value of this variable are 0.5 (when there is the same number of women and men on the board) and 0 (when there are only men or women directors), respectively. The second index is named after Shannon (Shannon, 1948 and Wie-

ner, 1961), and is measured as

$$
-\sum_{i=1}^{n} P_{i} \ln P_{i}
$$

, where $P_{i}$ and $n$ are defined in the same way as in the parentage of each category is the same. Both indexes are analogous but the Shannon index is more 
sensitive to small differences in the gender composition of the board (Baumgartner, 2006, goes into detail about the different between these two indexes). These two measures have been applied in several fields, including communication, linguistics, ecology, biology and economics.

The return on assets (ROA) was used as a measure of firm performance. Other variables included were the logarithm of the variability of ROA over the previous 5 years as a measure of a firm's operational risk (see Grace, 2004) and the level of debt, DEBT (calculated as the ratio of total debt to total assets), as a measure of financial risk. Several variables were incorporated that indicate the type of major shareholder: INDIVIDUAL (binary variable that takes a value of 1 when the major shareholder is an individual and 0 otherwise), NONFINANCIAL (binary variable that takes a value of 1 when the major shareholder is a non-financial firm and 0 otherwise).

Finally, a number of control variables were used, specifically, the age of the firm, AGE, the firm size measured by the logarithm of total assets, SIZE and the logarithm of the total number of directors. See Morck et al. (1988), Yermack (1996), Carter et al. (2003), Farrell and Hersch (2005) and others

Table 1 reports the descriptive statistics for all variables. The most important conclusion is that the mean percentage of women on Spanish boards of directors is 8.6 percent. This percentage is low but it is higher than the value calculated for large Spanish firms (about 3 percent; see Heidrick and Struggles, 2007). Moreover, only 23 percent of Spanish SMEs have one or more women on their boards.

\begin{tabular}{|c|c|c|c|c|c|}
\hline \multicolumn{6}{|c|}{ Table 1 Descriptive statistics } \\
\hline & Mean & Median & Standard Deviation & Minimum & Maximum \\
\hline $\mathrm{ROA}$ & 5.881 & 7.090 & 15.373 & $-149,980$ & 174.006 \\
\hline WOMEN RATIO & 8.600 & 0.000 & 20.100 & 0.000 & 100.00 \\
\hline PRESENCE OF WOMEN & 0.230 & 0.000 & 0.421 & 0.000 & 1.000 \\
\hline BLAU & 0.078 & 0.000 & 0.160 & 0.000 & 0.500 \\
\hline SHANNON & 0.115 & 0.000 & 0.232 & 0.00 & 0.690 \\
\hline OPERATIONAL RISK & 6.200 & 6.703 & 2.049 & -1.832 & 10.769 \\
\hline$\overline{\text { DEBT }}$ & 0.616 & 0.650 & 0.221 & 0.000 & 0.999 \\
\hline AGE & 8.664 & 8.625 & 0.530 & 6.159 & 10.545 \\
\hline INDIVIDUAL & 0.627 & 1.000 & 0.483 & 0.000 & 1.000 \\
\hline NONFINANCIAL & 0.357 & 0.000 & 0.479 & 0.000 & 1.000 \\
\hline SIZE & 14.575 & 14.550 & 1.553 & 6.891 & 17.577 \\
\hline NUMBER OF DIRECTORS & 2.648 & 3.000 & 2.564 & 1.000 & 48.000 \\
\hline LNUMBER OF DIRECTORS & 0.974 & 1.099 & 0.804 & 0.000 & 5.521 \\
\hline \multicolumn{6}{|c|}{$\begin{array}{l}\text { Variables: ROE (return on equity, \%), WOMEN RATIO (percentage of women on the board of directors), PRESENCE OF } \\
\text { WOMEN (binary variable that takes a value of } 1 \text { when there is at least one woman on the board of directors, and } 0 \text { otherwise), } \\
\text { BLAU (Blau Index of diversity), SHANNON (Shannon Index of diversity), OPERATIONAL RISK (firm operational risk, } \\
\text { calculated as the logarithm of standard deviation of ROA five year before the annual observation), DEBT (financial risk, } \\
\text { calculated as total debt over total assets), AGE (logarithm of firm age), INDIVIDUAL (binary variable that takes a value of } 1 \\
\text { when the major shareholder is an individual or familiar, and } 0 \text { otherwise) NONFINANCIAL (binary variable that takes a } \\
\text { value of } 1 \text { when the major shareholder is a non-financial firm, and } 0 \text { otherwise), SIZE (logarithm of the book value of the } \\
\text { total assets of the firm), NUMBER OF DIRECTORS (total number of directors on the boardroom), LNUMBER OF DIREC- } \\
\text { TORS (logarithm of the number of directors on the boardroom). }\end{array}$} \\
\hline
\end{tabular}

\section{METHODOLOGY}

To analyze the relationship between gender diversity on boards and firm performance the following equation was estimated:

$$
R_{i t}=\beta_{0}+\beta_{1} \text { DIVERSITY }_{i t}+\sum_{J=2}^{4} \beta_{j} C V_{j i t}+\psi_{t}+\eta_{i}+\varepsilon_{i t}
$$

where ROA represents firm performance, DIVERSITY includes, in separate analyses, the Women 
ratio, the Presence of women variable, the Blau Index or the Shannon Indexes (BLAU and SHANNON respectively). CV represents the control variables (DEBT, AGE and SIZE). The terms $\psi_{t}, \eta_{i}$

and $\varepsilon_{i t}$ symbolize the time effects, individual effect and random disturbance, respectively.

Model (1) is estimated using a panel data methodology, applying the Generalized Method of Moments (GMM) technique (Arellano and Bover, 1995 and Blundell and Bond, 1997). This procedure makes it possible to control, first, for individual heterogeneity, introducing an individual effect, $\square_{i}$ (Himmelberg et al., 1999) and, second, for macroeconomic effect on the dependent variable using time dummy variables. In addition, GMM estimation resolves the trouble of endogenity that can appear when the independent variables and the dependent variable are determined simultaneously. To remove this bias, this methodology estimates a system of two simultaneous equations, one in levels (using first differences instruments) and other in first differences with lagged levels instruments.

In the final model, the determinants of gender diversity are identified according to the following equation:

$$
\begin{aligned}
\text { DWOMAN }_{i t}= & \beta_{0}+\beta_{1} \text { ROA }_{i t}+\beta_{2} \text { OPERATIONALRISK }_{i t}+ \\
& +\beta_{3} \text { DEBT }_{i t} \sum_{j=4}^{5} \beta_{j} \text { MAIN }_{j i t}+\sum_{j=6}^{8} \beta_{j} C V_{j i t}+\psi_{t}+\eta_{i}+\varepsilon_{i t}
\end{aligned}
$$

where OPERATIONALRISK and DEBT measure the firm's operational risk and the financial risk, respectively. MAIN symbolizes the dummies relative to the type of main shareholder (individual or non-financial). CV represents the control variables (SIZE, the logarithm of the number of directors and AGE). The other variables are as in Model (1).

To estimate this model, a logit panel data methodology was used which is adequate when the dependent variable is binary.

\section{RESULTS}

The results of estimating the Models (1) and (2) are shown in Tables 2 and 4. Table 2 resents the effect of gender diversity on firm performance, while Table 3 shows the determinants of women's presence on boards.

Panel A of Table 2 indicates that the presence of women on the board and the Women ratio have a positive and significant effect on firm performance, ROA. Alternatively the return on equity (ROE) has been used as a measure of firm performance and the results obtained are very similar. These results are not reported here to save space. Therefore, female representation on the boards creates an advantage for the firms and the positive effect of diversity on work groups (variety of opinions and strategies) outweigh the problems of integration and slowness in the taking of decisions. This result supports Hypothesis 1 and it in the line of the evidence given by Erhardt et al. (2003) and Carter et al. (2003), among others.

The effect of the Women ratio is greater than the effect of the Presence of women variable. This result indicates that increasing the number of women on boards is not only necessary for social justice but it also protects the interests of shareholders. Women bring a different style to board tasks and better environmental adaptation. This is a very important result for SMEs that have to face a competitive market environment.

For the control variables, the debt ratio has a negative and significant effect on firm performance. The negative relationship implies that SMEs may be averse to raising equity for fear of losing control of the firm and for this reason use more debt in their capital structure than would be desirable. Therefore, SMEs can have problems obtaining equity and may adopt an inappropriate capital structure. However, increasing debt may reduce agency conflicts, while employing excessive debt is likely to result in high bankruptcy costs with associated negative effects on performance (Abor, 2007). 
Table 2 The influence of the presence of women and women ratio and diversity indexes on Return on Assets (ROA)

\begin{tabular}{|c|c|c|c|c|}
\hline \multicolumn{5}{|c|}{ Panel A: The Presence of women and Women ratio } \\
\hline Variable & Standard Error & Coefficient & Standard Error & Coefficient \\
\hline Constant & 1.544 & $19.878 * * *$ & 1.518 & $19.240 * * *$ \\
\hline PRESENCE OF WOMEN & 0.423 & $1.154 * * *$ & & \\
\hline WOMEN RATIO & & & 0.653 & $1.321 * *$ \\
\hline DEBT & 0.353 & $-11.899 * * *$ & 0.351 & $-11.981 * * *$ \\
\hline AGE & 0.176 & $-1.432 * * *$ & 0.174 & $-1.428 * * *$ \\
\hline SIZE & 0.143 & $0.277 *$ & 0.140 & $0.333^{* *}$ \\
\hline \multicolumn{5}{|c|}{ Panel B: Diversity Indexes } \\
\hline Variable & Standard Error & Coefficient & Standard Error & Coefficient \\
\hline Constant & 1.537 & $19.550 * * *$ & 1.542 & $19.664 * * *$ \\
\hline BLAU & 0.944 & $2.481 * * *$ & & \\
\hline SHANNON & & & 0.678 & $1.773 * * *$ \\
\hline DEBT & 0.352 & $-11.978 * * *$ & 0.352 & $-11.960 * * *$ \\
\hline AGE & 0.175 & $-1.490 * * *$ & 0.176 & $-1.483 * * *$ \\
\hline SIZE & 0.140 & $0.342 * *$ & 0.141 & $0.329 * *$ \\
\hline \multicolumn{5}{|c|}{$\begin{array}{l}\text { Notes: } \\
* * *, * *, * \text { denote significance at } 1 \%, 5 \% \text { and } 10 \% \text { levels, respectively. } \\
\text { Variables: PRESENCE OF WOMEN (binary variable that takes a value of } 1 \text { when there is at least one woman } \\
\text { on the board of directors, and } 0 \text { otherwise); WOMEN RATIO (percentage of women on the board of directors); } \\
\text { BLAU (Blau Index of diversity); SHANNON (Shannon Index of diversity); DEBT (total debt over total assets); } \\
\text { AGE (logarithm of firm age); SIZE (firm size measured by the logarithm of total assets. }\end{array}$} \\
\hline
\end{tabular}

In Panel B of Table 2 the Blau index measures the gender diversity of the board of directors. Some researchers (Ancona and Caldwell, 1992; Randel, 2002, among others) affirm that this index is more suitable to measure the diversity than the Women ratio because a board composes only of women lacks gender diversity. The Blau index has a maximum value when there is the same number of women and men on the board of directors. Results are like to those shown in Panel A. This suggests that a mixture of men and women promotes more effective boards.

To test the robustness of the results an alternative diversity index is included in panel B. The Shannon index shows a positive and significant effect on firm performance, in the line with the results shown in Panel A of Table 2. It can be seen that the coefficients of the Blau and Shannon Indexes are higher than the coefficients for the Presence of women and Women ratio, while the coefficients of the other independent variables remain similar to those found earlier. This means that the impact of gender diversity increases continuously up to the point where the diversity of the board is maximised. This result indicates the importance of adding women directors to the board and the significance of a mix of women and men to create adequate gender diversity on the board. Finally, the control variables have the same signs those observed in Panel A.

The influence of the firm's age (AGE) on firm performance is negative, too. This result suggests that younger firms maybe have less inertia and fewer bureaucratic processes. They can be more agile and flexible in response to environmental changes.

Finally, in the sample, firms with more assets (SIZE) have a higher performance in terms of ROA. This last result is not what was expected, and it may be a consequence of the difficulties in obtaining suitable funding on the part of smaller SMEs. 
The last analysis consists in testing for some determinants of women's presence on the board of directors. Table 3 shows the results and indicates that the firm's performance, ROA, does not have a significant impact on the presence of women. There is no indication that women are choosing to serve on the boards of firms with higher levels of performance. This result does not support the Hypothesis 2 and can be explained by the notion that the boards of better performing firms will prefer to maintain board diversity when a new director is appointed.

\section{Table 3. The determinants of the presence of women on the board of SMEs}

\begin{tabular}{|l|c|c|}
\hline Variable & Standard Error & Coefficient \\
\hline Constant & 1.898 & $-11.264^{* * *}$ \\
\hline ROA & 0.003 & 0.001 \\
\hline OPERATIONAL RISK & 0.070 & 0.014 \\
\hline DEBT & 0.361 & $-0.936^{* *}$ \\
\hline INDIVIDUAL & 0.592 & $1.158^{*}$ \\
\hline NONFINANCIAL & 0.574 & $-1.219^{* *}$ \\
\hline SIZE & 0.067 & $-0.358^{* * *}$ \\
\hline LNUMBER OF DIRECTORS & 0.134 & $5.138^{* * *}$ \\
\hline AGE & 0.188 & -0.081 \\
\hline $\begin{array}{l}\text { Notes: } \\
* * * * *, * \text { denote significance at 1\%, 5\% and 10\% levels, respectively. }\end{array}$ \\
$\begin{array}{l}\text { Variables: ROA (Return on Assets); OPERATIONAL RISK (firm operational risk, calculated as the } \\
\text { logarithm of the variability of Return on Assets); DEBT (financial risk, calculated as total debt over } \\
\text { total assets); INDIVIDUAL (binary variable that takes a value of 1 when the major shareholder is an } \\
\text { individual, and 0 otherwise); NONFINANCIAL (binary variable that takes a value of 1 when the } \\
\text { major shareholder is a non-financial firm, and 0 otherwise); SIZE (firm size measured by the loga- } \\
\text { rithm of total assets); LNUMBER OF DIRECTORS (logarithm of the number of directors on the } \\
\text { boardroom); AGE (logarithm of firm age). }\end{array}$ \\
\hline
\end{tabular}

For the effect of firm risk on female representation on the boardroom, there is no significant relationship between firm operational risk and the probability of presence of women directors. Thus, women are not affected in their decision to join a board by the risk derived from internal processes, people and systems, or from external events. This result is does not support the Hypothesis 3. However, a negative and significant effect on the representation of women among directors was found in the case of financial risk, DEBT, which does accord with Hypothesis 3. This suggests that women prefer to serve on boards with low levels of debt and low probability of bankruptcy and it confirms a certain risk aversion. Possibly women take financial risk into account because it is easier to identify before joining the board than operational risk.

Firms with an individual as major shareholder (family firms) have more women on their boards of directors. However, when of a non-financial firm is the main shareholder, the probability of women's presence on the board diminishes. This confirms Hypothesis 4 and it implies that gender discrimination persists in society in general but that it is overcome by family ties, which may help to eliminate prejudice and stereotypes. It is probably easier to achieve a positive work-life balance in family firms (Mateos et al. 2006). Consequently, promoting this type of firm can improve the number of women engaged in senior management. The results also indicate that the logarithm of total assets (SIZE) has a negative impact on gender equality. This evidence reinforces the notion that small and family firms are more likely to appoint women to their boards of directors. The logarithm of the number of directors has a positive impact on the women presence on the board. It is logical that larger boards are more likely to include women. Finally, the age of the firm (AGE) does not seem to be a determinant of women's presence. 


\section{CONCLUSIONS}

This paper examines the impact of the gender composition of boards of directors of Spanish SMEs. Spain can be characterized as a country where the incorporation of women in top management positions has been low, a situation that does not seem to have improved in recent years. The debate on this topic has been intense for two reasons: the passing of the Spain's Unified Good Governance Code (2006) which recommends an increase in the number of women directors until they are a minimum of 40\% in 2015 for listed firms and the Gender Equality Act endorsed by the Spanish parliament in 2007.

The effect of women's presence on the board of directors, measured by several variables, on firm performance and the determinants of female presence on the board have been examined, using panel data methodology.

One of the contributions of this study is that it is focused on SMEs when the majority of previous evidence was taken from listed firms. SMEs are more important in terms of number, employment and sales. A second contribution arises from the fact that existing studies have not used panel data to control for potential bias in the estimation procedure.

The proportion of women on the boards of Spanish SMEs is higher than that in Spanish listed firms. This implies that SMEs are more advanced in term of gender equality.

A mix of men and women on the board has a positive effect on firm performance. This result suggests that gender diversity not only an advances social equity in Spanish boardrooms but serves to improve the firms' economic situation. The presence of an individual or a non-financial firm as main shareholder has a positive or negative impact, respectively, on female representation on the board. Consequently, it can be concluded that family firms increase gender equality on their boards.

It was also found that women do not show a preference for working on boards of better performing firms or those with lower levels of operational risk. However, they do prefer to be on the boards of firms with less financial risk. Finally, smaller firms and larger boards have more women as directors.

For future research, it would be interesting to analyse the internal processes that increase the firm performance depending on the composition of the board of directors of Spanish SMEs, identifying the different tasks and contributions that women and men can make. 


\section{REFERENCES}

Abor, J. (2007), Debt policy and performance of SMEs: evidence from Ghanaian and South African firms, Journal of Risk Finance, 8, pp.364-379.

Adams, R.B., and Ferreira, D.B. (2002), Diversity and incentives in teams: Evidence for corporate boards. University of Chicago: Dissertation.

Ancona, D.G., and Caldwell, D.F. (1988), Beyond task and maintenance: Defining external functions in groups, Group and Organization Studies, 13, pp.468-494.

Ancona D.G. and Caldwell, D.F. (1992), Demography and design: Predictors of new product team performance, Organization Science, 3, pp.321-341.

Arellano M. and Bover O. (1995), Another look at the instrumental variable estimation of errorcomponents models, Journal of Econometrics, 68, pp.29-51.

Baumgartner, S. (2006), Measuring the diversity of what? And for what purpose? A conceptual comparison of ecological and economic biodiversity indices, Working paper, Social Science Research Network, SSRN.

Bilimoria, D. (1995), Women director: the quiet discrimination, Corporate Board, July/August, pp. 10 -14 .

Bilimoria, D. and Piderit, S.K. (1994), Board committee membership: effect of sex -based bias, Academy of Management Journal, 37, pp.1453-1477.

Blau, P. M. (1977), Inequality and Heterogeneity, New York: The Free Press.

Blundell, R. and Bond, S. (1997), Initial conditions and Moment Conditions in Dynamic Panel Data Models, Journal of Econometrics, 87, pp.115-143.

Böhren, Ø. and Ström, R.Ø. (2007), Aligned, informed, and decisive: characteristics of value-creating boards, Working paper, Social Science Research Network, SSRN.

Brammer, S., Millington, A. and Pavelin S. (2007), Gender and Ethnic Diversity Among UK Corporate Boards, Corporate Governance: An International Review, 15, pp.393-403.

Brancato, C.K. and Patterson, D.J. (1999), Board diversity in U.S. corporations: Best practices for broadening the profile of corporate boards, New York: Research Report 1230-99 - The Conference Board.

Brown, S.A. and Segal P. (1989), Female Entrepreneurs in Profile, Toronto: Canadian Banker, JulyAugust, pp.32-34.

Carleton, W.T., Nelson, J.M. and Weisbach, M.S. (1998), The influence of institutions on corporate governance through private negotiations: Evidence from TIAA-CREF, Journal of Finance, 53, pp.1335-1362.

Carter, D.A., Simkins, B.J. and Simpson W.G. (2003), Corporate governance, board diversity, and firm value, Financial Review, 38, pp.33-53.

Castaldi, R. and Wortman, M. (1984), Boards of directors in small corporations: An untapped resource, American Journal of Small Business, 9, pp.1-10.

Catalyst (2004), The bottom line: Connecting corporate performance and gender diversity, New York: Catalyst.

Chaganti, R. (1986), Management in Women Owned Enterprises, Journal of Small Business Management, October, pp.18-29.

Collerette P. and Aubry, P.G. (1990), Socio-Economic Evolution of Women Business Owners in Quebec, Journal of Business Ethics, 9, pp.417-22. 
Corporate Women Directors International Report (2007), Women Board Directors of the Fortune Global 200.

Cummings, A., Zhou, J. and Oldham, G.R. (1993), Demographic differences and employee work outcomes: Effects on multiple comparison groups, Annual Meeting of the Academy of Management, Atlanta.

Daily, C.M., Certo, S.T. and Dalton, D.R. (1999), A decade of corporate women: Some progress in the boardroom, none in executive suite, Strategic Management Journal, 20, pp.93-99.

Daily C.M. and Dalton, D.R. (2003), Women in the boardroom: A business imperative, Journal of Business Strategy, 24, pp.8-9.

Daily, C.M., McDougall, P.P., Covin, J.G. and Dalton, D.R. (2002), Governance and strategic leadership in entrepreneurial firms, Journal of Management, 28, pp.387-412.

Du Rietz, A. and Henrekso M. (2000), Testing the female underperformance hypothesis, Small Business Economics, 14(1), pp.1-10.

Ely, R.J. (1994), The effects of organizational demographics and social identity on relationships among professional women, Administrative Science Quarterly, 39, pp.203-238.

Erhardt, N.L., Werbel, J.D. and Shrader, C.B. (2003), Board of directors diversity and firm financial performance, Corporate Governance: An International Review, 11, pp.102-111.

Erkut, S. (2006), Critical Mass on Corporate Boards: Why Three or More Women Enhance Governance. Wellesley: Research \& Action Report, 28.

Farrell, K.A. and Hersch, P.L. (2005), Additions to corporate boards: the effect of gender, Journal of Corporate Finance, 11, pp.85-206.

Fenwick, G.D. and Neal, D.J. (2001), Effect of gender composition on group performance, Gender, Work and Organization, 8, pp.205-225.

Forbes, D.P. and Milliken, F.J. (1999), Cognition and corporate governance: Understanding boards of directors as strategic decision-making groups, Academy of Management Review, 24, pp.489-505.

Fray, D. and. Guillaume, Y.R (2007), Team diversity, in International Encyclopedia of Organization Studies. Eds. S. R. Clegg and J. R. Bailey. Los Angeles: Sage.

Gabrielson, J. (2003), Board and governance in SMEs: An inquiry into boards' contribution to firm performance. Lund: Scandinavian Institute for Research in Entreprenneurship.

Gorman, M. and Sahlman, W. (1989), What do venture capitalists do? Journal of Business Venturing, 4, pp.231-248.

Grace, E. (2004), Contracting incentives and compensation for property-liability insurer executives, Journal of Risk and Insurance, 71, pp.285-307.

Hambrick, D.C. (1994), Top management groups: A conceptual integration and reconsideration of the team label, in Research in organizational behavior. Ed. B. M. Staw. Greenwich: JAI Press, 16, pp.171213.

Hambrick, D.C. and Finkelstein, S. (1987), Managerial discretion: A bridge between polar views of organizational outcomes, in Research in organizational behavior. Eds. L. L. Cummings and B. M. Staw. Greenwich: JAI Press, 9, pp.369-406.

Harel, G.H., Tzafrir, S.S. and Baruch, Y. (2003), Achieving organizational effectiveness through promotion of women into managerial positions: HRM practice focus, International Journal of Human Resource Management, 14, pp.247-263.

Harrison, D.A. and Klein, K.J. (2007), What's the difference? Diversity constructs as separation, variety, or disparity in organizations, Academy of Management Review, 32, pp.1199-1228.

Heidrick and Struggles (2007), Corporate Governance in Europe, Paris: 2007 Report. 
Hillman, A.J., Cannella, A.A. and Harris, I.C. (2002), Women and racial minorities in the boardroom: how do directors differ? Journal of Management, 28, pp.747-63.

Himmelberg, C.P., Hubbard, R.G. and Palia D. (1999), Understanding the determinants of managerial ownership and the link between ownership and performance, Journal of Financial Economics, 53, pp.353-384.

Holmes, S. (2008), Smashing the glass ceiling. BBC News online, 11 January.

Jackson, S.E., Brett, J.F., Sessa, V.I., Cooper, D.M., Julin, J.A. and Peyronnin, K. (1991), Some differences make a difference: Individual dissimilarity and group heterogeneity as correlates of recruitment, promotions, and turnover, Journal of Applied Psychology, 76, pp.675-689.

Jackson, S.E., May, K.E. and Whitney K, (1995), Understanding the dynamics of diversity in decision making teams, in Team effectiveness and decision making in organizations. Eds. R. A. Guzzo and E. Salas. San Francisco: Jossey-Bass, pp.204-261.

Jehn, K.A. and Bezrukova, K. (2004), A field study of group diversity, group context, and performance, Journal of Organizational Behavior, 25, pp.1-27.

Jianakoplos, N.A., and Bernasek, A. (1998), Are Women More Risk Averse? Economic Inquiry, 36, pp.620-630.

Judge, W.Q. and Zeithaml C. (1992), Institutional and strategic choice perspectives on board involvement in the strategic decision process, Academy of Management Journal 35, pp.766-794.

Kesner, I.F. (1988), Directors' characteristics and committee membership: an investigation of type, occupation, tenure and gender, Academy of Management Journal, 31, pp.66-84.

Kildar, L., Mihailescu, A., Nolan, C. and Schreve, F. (2009), Women on boards of directors: the case study of Norway, MBA-HSG

Lau, D.C., and Murnighan, J.K. (1998), Demographic diversity and faultlines: The compositional dynamics of organizational groups, Academy of Management Review, 23, pp.325-340.

Loden, M. (1985), Feminine leadership, or how to succeed in business without being one of the boys. New York: Times Books.

Mateos de Cabo, R., Gimeno, R. and Lorenzo, E. (2006), Análisis de la presencia de la mujer en los consejos de administración de las mil mayores empresas españolas, Working paper, Fundación de las Cajas de Ahorro, 263.

Milliken, F.J. and Martins, L. (1996), Searching for common treads: Understanding the multiple effects of diversity in organizational groups, Academy of Management Journal, 21, pp.402-433.

Morck, R., Sheleifer, A. and Vishny, R.W. (1988), Management ownership and market valuation: An empirical analysis, Journal of Financial Economics, 20, pp.293-315.

Morrison, A. (1992), The new leaders: Guidelines on leadership diversity in America. San Francisco: Jossey-Bass.

Olsen, S. and Currie, H.M. (1992), Female Entrepreneurs: Personal Value Systems and Business Strategies in a Male Dominated Industry, Journal of Small Business Management, January, pp.49-57.

Pfeffer, J. (1981), Management as symbolic action: The creation and maintenance of organizational paradigms, in Research in organizational behavior. Eds. L. L. Cummings and B. M. Staw. Greenwich: JAI Press, 3, 1-52.

Randel AE (2002), Identity salience: A moderator of the relationship between group gender composition and work group conflict. Journal of Organizational Behavior 23:749-766.

Randøy, T., Thomsen, S. and Oxelheim, L. (2006), A Nordic Perspective on Corporate Board Diversity, Paper presented at European International Business Academy Annual Conference, Fribourg. 
Richard O.C. (2000), Racial diversity, business strategy, and firm performance: A resource-based view, Academy of Management Journal, 43, pp.164-177.

Robinson, G. and Dechant, K. (1997), Building a business case for diversity, Academy of Management Executive, 11, pp.21-30.

Rose, C. (2007), Does female board representation influence firm performance? The Danish evidence, Corporate Governance: An International Review, 15, 2, pp.404-413.

Scherr, F.C., Sugrue, T.F. and Ward, J.B. (1993), Financing the Small Firm Start-Up: Determinants of Debt Use, The Journal of Small Business Finance, 3, pp.17-36.

Segal, T. (1996), Corporate directors: The female effect, Executive Female, November/December, pp. 46-49.

Shannon, C.E. (1948), A mathematical theory of communication, Bell System Technical Journal, 27, pp.379-423.

Shrader, C.B., Blackburn, V.B. and Iles, P. (1997), Women in management and firm financial value: An exploratory study, Journal of Managerial Issues, 9, pp.355-372.

Simpson, E.H. (1949), Measurement of diversity, Nature, 163, p.688.

Smith, N., Smith, V. and Verner, M. (2006), Do women in top management affect firm performance? A panel study of 2,500 Danish firms, International Journal of Productivity and Performance Management, 55, pp.569-593.

Stirling, A. (1998), On the Economics and Analysis of Diversity, Working paper, Science Policy Research Unit Electronic.

Tsui, A.S., Egan, T.D. and O'Really, C.A. (1992), Being different: Relational demography and organizational attachment, Administrative Science Quarterly, 37, pp.549-579.

Wagner, G.W., Pfeffer, J. and O'Reilly, C.A. (1984), Organizational demography and turnover in topmanagement groups, Administrative Science Quarterly, 29, pp.74-92.

Warren, R. (2003), Corporate governance for competitive advantage in SMEs, in Competitive advantage in SMEs: Organising for innovation and change. Eds. O Jones and F. Tilley. Chichester: Wiley \& Sons,

Watson, W.E., Kumar, K. and Michaelsen, L.K. (1993), Cultural diversity's impact on interaction process and performance: comparing homogeneous and diverse task groups, Academy of Management Journal, 36, pp.590-602.

Welbourne, T.M., Cycyota, C.S. and Ferrante, C.J. (2007), Wall Street Reaction to Women in IPOs, Group and Organization Management, 32, pp.524-547.

Wiener, N. (1961), Cybernetics, Cambridge: MIT Press.

Yermack, D. (1996), Higher market valuation of companies with a small board of directors, Journal of Financial Economics, 40, pp.185-211.

Zelechowski, D.D. and Bilimoria, D. (2004), Characteristics of Women and Men Corporate Inside Directors, Corporate Governance: An International Review, 12, pp.337-342. 